Meta

Journal des tradlucteurs

Translators' Journal

\title{
Why Not "sur la ferme"? A Case of Linguistic Interference
}

\section{Irène V. Spilka}

Volume 15, numéro 4, décembre 1970

URI : https://id.erudit.org/iderudit/004226ar

DOI : https://doi.org/10.7202/004226ar

Aller au sommaire du numéro

Éditeur(s)

Les Presses de l'Université de Montréal

ISSN

0026-0452 (imprimé)

1492-1421 (numérique)

Découvrir la revue

Citer cet article

Spilka, I. V. (1970). Why Not "sur la ferme"? A Case of Linguistic Interference. Meta, 15(4), 212-219. https://doi.org/10.7202/004226ar d'utilisation que vous pouvez consulter en ligne.

https://apropos.erudit.org/fr/usagers/politique-dutilisation/ 


\title{
Why Not $\mathbf{6}$ sur la ferme 9 ?
}

\author{
A CASE OF LINGUISTIC INTERFERENCE
}

\begin{abstract}
«The linguist's task is to identify and describe all cases of interference and to cooperate with other social scientists in accounting for them. "

EnNar HaUgen 1
\end{abstract}

A frequently observed case of interference among English-French bilinguals is the translation of on by sur in phrases such as « on the street », « on the farm », « on the train ». The aim of the present paper is to ask what kinds of rules are being violated when this occurs.

\section{A QUESTION OF TERMINOLOGY}

The term interference was defined by Weinreich as «those instances of deviation from the norms of either language which occur in the speech of bilinguals as a result of their familiarity with more than one language, i.e. as a result of language contact $\gg(1953$, p. 1). These may be found either in the speech of « the bilingual speaker as a result of his personal knowledge of the other tongue s (p. 11), or in the language of his community where «their use is no longer dependent on bilingualism $\gg$ (ibid.); in their case they might affect linguistic elements of any hierarchical level, namely phonological, grammatical and semantic.

Haugen, further refined the concept and distinguished switching, «the alternate use of two languages $»$, interference, «the overlapping of two languages $»$ and integration, «the regular use of materials from one language in another, so that there is no longer either switching or overlapping, except in a historical sense » (Haugen, 1956, p. 40, quoted by Diebold, 1960, in Language in Culture and Society, p. 497).

The original notion as well as the subsequent refinements fail to take into account the intractable question of boundaries between adjacent « speech communities $\gg$. When a native Montrealer spontaneously says : Je l'ai rencontré sur 1. Bilingualism in the Americas, 1956, p. 11. 
la rue he is unaware of committing an anglicisme, the popular term of opprobrium used to castigate the introduction of English elements into French, for the simple reason that for him «interference» has become «integration». Yet this same Montrealer would take offense at the suggestion that he does not speak Standard French, save for his « accent » and a few « words . The variety of French spoken in Canada does not officially admit of any differences other than phonological, which it seeks to eradicate, and lexical, which it includes in specialized dictionaries with growing parsimony. One needs only compare Bélisle's Dictionnaire général de la langue française au Canada, 1957, with the Dictionnaire canadien/The Canadian Dictionary, 1962, to detect a trend toward «normalization » of Canadian French, i.e. bringing it ever closer to the French spoken in France. Frenchmen, however, never fail to be struck by the differences which set the Quebec vernacular apart from their own tongue, but vary greatly in their response to it. Some find it quaint but easy to understand, others think it a disgrace, an affront to the dignity of man, an impoverished language difficult to comprehend and quite unsuitable to the expression of well-formed ideas. Frenchmen do not fail to label the example quoted above as a mistake, thus indicating that they recognize it as a case of interference in speech. Are we then to say that Canadians and Frenchmen speak two different languages because the former have integrated certain English patterns while the latter have not?

Chomsky's competence-performance dichotomy can be useful at this point. Competence is what a person knows, while performance is what he does under certain circumstances extraneous to language proper. Switching and interference tend to occur as a result of extra-linguistic pressures, such as the presence of foreigners, fatigue, distraction, etc.; integration, on the other hand, refers to a rule of the speaker's particular grammar, and therefore it occurs with regularity. Since competence includes the ability to interpret ambiguous, incomplete, tautological and otherwise anomalous sentences, it is not surprising that the average Frenchman should be able to decipher the anglicized sentence Je l'ai rencontré sur la rue while the French-Canadian can comprehend Standard French Je l'ai rencontré dans la rue. Yet this ability does not change the fact that each of these two speakers generates the sentences of his language by means of two somewhat different sets of rules.

To sum up, this writer would define interference as an event occurring in the performance of bilingual speakers, and integration as a grammar rule whose origin can be traced to contacts between languages. This has the advantage of focusing directly on the linguistic aspect of the problem, thus isolating it from the underlying psychological processes, which can then be labeled independently and treated by appropriate techniques. Selinker (1969) has suggested the name «transfer » and outlined a method for this.

Another question raised in connection with language contacts concerns the notion of « rules of speaking » or « use » as opposed to « usage ». «Usage » refers to rules governing well-formed utterances, but as Dell Hymes $(1967$, p. 16) pointed out «in socialization a child acquires not only language(s), but also sets of attitudes and habits with regard to the value and utilization of language(s)... There 
may be what linguists have come to call interference (Weinreich, 1953) not only between two sets of code habits, but also between two sets of habits for the use of codes. » Such habits may be widely divergent from one speech community to another, as when one prescribes silence in a situation where the other makes talking the rule, or the differences may be so subtle as to merge with rules of usage (grammar) and blur the boundaries between the two. An example of this is the differential use of terms of address after «please » and «thank you » in English and French. In «please, Dad » there is a note of pleading which is absent from s'il vous plaît, papa although, strictly speaking, both utterances are possible in a neutral context.

The question of «use » v. « usage » is relevant to this paper inasmuch as interference can occur in both areas and the need arises to specify the nature of the rules involved in each case.

\section{THE PROBLEM}

A common error consists in translating «on the street», « on the farm», « on the train » and similar expressions, by sur la rue, sur la ferme and sur le train when the appropriate form would be dans la rue, dans une ferme and dans le train, as in the following examples ${ }^{2}$ :

1) He has been working on a farm. * Il a travaillé sur une ferme.

Il a travaillé dans une ferme.

2) It is forbidden to get on the train with a dog. *Il est interdit de monter sur le train avec un chien. Il est interdit de monter dans le train avec un chien.

3) I met him on St. Catherine Street. * Je l'ai rencontré sur la rue Sainte-Catherine. Je l'ai rencontré dans la rue Sainte-Catherine.

The speaker's primary language seems to have little bearing on frequency of occurrence, but direction of interference is invariant, that is from English into French. We may well ask why this should be so, and then what rules of Standard French grammar are being violated. The prestige of English has often been advanced as a cause ; as to the nature of the mistake, it is usually summarily dismissed with an assumption of imitation.

In the following sentences, sur la ferme, le train, la rue are perfectly legitimate strings :

4) Un mystère planait sur la ferme des Mimosas.

5) Il était debout sur le train le dos tourné à la locomotive, et agitait les bras.

6) Ma fenêtre donne sur la rue.

The same can be said of travailler, monter, rencontrer sur in the following :

7) Il travaille sur le plateau (mais habite dans la vallée).

8) Il est monté sur le toit à l'aide d'une échelle.

9) Je l'ai rencontré sur le pont.

2. Rules for the translation of the definite article will not be considered in this paper. 
Finally travailler sur la ferme and monter sur le train can be found in well-formed sentences, such as :

10) Il travaille sur la ferme mais il va redescendre pour déjeuner.

11) Il est monté sur le train au risque de se casser la figure.

It should be clear by now that the interference in question is not located at the surface level. In other words, *il travaille sur la ferme is not ungrammatical in the same way as *il siège sur le comité.

We may then ask whether a semantic rule is being violated. Daswan has shown that, in English at least, prepositions tend to fall into groups or sets, each of which denotes a semantic notion when combined with particular sets of nouns and predicates in specific adverbial phrases, e.g. in, on and at denote « rest $»$ or «presence » in relation to a noun of location $(1969$, p. 33 et seq.). He has further demonstrated that semantic notions are not simple, but composed of bundles of features, an idea clearly reminiscent of Jakobson's distinctive features in phonological theory. Daswan was concerned with the semantic features of prepositions within one language; we are interested in the contrast between the meanings of prepositions in two languages and we wish to find out when these coincide and when they diverge for a given pair of forms, namely on and sur. What we need is therefore a method of contrastive analysis.

\section{CONTRASTIVE SEMANTIC ANALYSIS}

In the absence of an adequate general semantic theory, several methods have been proposed to investigate the meaning of words. Of these, distributional, componential, and combinatory analysis are probably the better known. All of them however, have concentrated on the study of larger units with a clear denotational field such as nouns and verbs, preferably of the well-ordered variety such as kinship terms, names of colours, plants, animals, etc. The study of prepositions, by comparison, has been neglected. Recent grammars treat the subject cursorily ; some journal articles have appeared, but restrictions imposed by the genre make full treatment of the question unlikely if not altogether impossible. Daswan's thesis is a substantial contribution, but it focuses on adverbial phrases rather than on prepositions per se, which he defines as «semantic units that have derivational function $\gg(1969$, p. 17) thus emphasizing their syntactical role and subordinating their meaning to their function.

Viggo Brøndal (1950) has constructed a theory of prepositions based on logical principles which has the advantage of being systematic, coherent and differential : sets of prepositions in twenty-three languages are compared within the framework of a nine-dimensional matrix comprising the following categories : symetrical, asymetrical, symetrical-asymetrical ; transitive, intransitive, transitiveintransitive (see Brøndal, p. 134-135, for a comparison of English and French prepositions). Other dimensions and aspects, such as connexity, numeration, complexity, polarity, affirmation and negation, are considered throughout the work and it is suggested that many others will be isolated as more languages are analyzed. The intended result would be a panoramic view of the relational system of each 
language of such richness and complexity as to be unwieldy. Yet Brøndal's contribution deserves attention for two reasons : $a$ ) his definition of prepositions ; $b$ ) his observation concerning the constancy and generality of meaning under the apparent variability and particularity of speech events.

Prepositions, in Brøndal's view, are those elements of a language which express relations in general :

Pour ce qui est de la classe comme telle, elle semble suffisamment définie si on dit qu'elle exprime la relation en général; à l'intérieur de ce cadre, il faudra donc définir chaque préposition particulière comme la somme de relations spéciales $(1950$, p. 11).

This definition does away with the traditional morphological and syntactic approach and permits treating as single units forms that function equally as conjunctions and adverbs. This is not only more economical, but also more coherent from the point of view of semantic analysis, for it stands to reason that if a linguistic sign is the association of a concept and an acoustical image (in Saussure's terms), or (in Daswan's words) if language is the relation of meanings to sounds, there must be a constant relation between a given sound string and a given meaning regardless of the syntactic function this given unit performs in the sentence.

If meaning is perceived and understood intuitively in the act of communication, it can and should be definable in terms of logical principles when language analysis is attempted. Modern logic has shown that space and time were not discontinuous entities, but concrete relations which could both be subsumed under the more abstract concept of extension. It is therefore more logical to begin the investigation of prepositional meaning by a search of their general meanings, and then to seek how this becomes differentiated when applied to the denotation of time and space. The task of semantic theory of prepositions, according to Brøndal, is therefore to establish broad relational categories which satisfy the following conditions: 1) these categories must be independent of grammatical classification ;2) they must not rely on any form of intuition, and 3) they must, alone, or in combination, be able to define all existing prepositions (Brøndal, 1950, p. 33-34; our translation). The three main types of relations are symetry, transitivity and connexity (p. 29 ; for a complete description see p. 33 to 51 ). When properly conducted, this operation leads to the discovery, confirmed by observation and intuition, that there are no prepositions specialized in the expression of time, space or general relations exclusively, but that each form has its meaning specified by a set of distinctive traits regardless of the particular use which is made of it in the act of speech (p. 71-72). The linguist then has his work cut out for him :

Ceci offre au grammairien des tâches étendues et intéressantes : il devra examiner comment chaque espèce de relation (chacune avec des différentes formes - jusqu'à 5) se présente lorsqu'elle est saisie intuitivement par un logicien ou un mathématicien, un biologue, - ou un homme pratique, un paysan ou un artisan par ex.; ensuite il lui faudra combiner toutes ces modifications intuitives des plus simples relations, et, enfin, les retrouver comme manifestations nécessaires de la définition générale de la préposition particulière (p. 72).

To take up this challenge, we undertook a two-way comparison of English on and in, and French sur and dans, that is across languages for each preposition 
and across prepositions within each language. We hoped this would help us gain some insight into the grammar of bilinguals who regularly exhibit the on/sur integration.

Minimal semantic pairs were constructed on the model of minimal phonological pairs, i.e. two strings were selected which differed by only one element, in this case a lexical unit. A criterion for selection was that the members of the pair be autonomous; in other words each one should be able to function either as an independent utterance, or as a formant of a larger unit which would constitute an identical context for both. An example of the latter is « on time : in time » either of which can follow the segment " he will do it 》.

Comparison between both members of a pair yielded differential meanings, that is, meanings resulting from a contrastive operation, and not necessarily denotative or referential meanings. We considered these to be distinctive semantic features.

The next step was to arrange them in such a way as to account for the total meaning of each preposition. This was no mean task, and the results suggested in this paper are to be considered tentative rather than definitive.

Since on, in, sur and dans clearly refer, amongst other things, to time and space which, as was stated above, are but two functions of the broader concept of extension, a three-way classification immediately suggests itself. This can be represented diagrammatically :

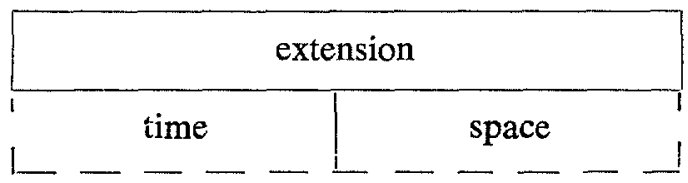

Within each of the two categories of time and space, a logical order can be found, such as beginning-during-after, or external-contiguous-above. The traits thus ordered can then be summerized and organized in similar fashion into the category of extension.

It can then readily be seen that the meanings of the two prepositions do not coincide in both languages; which is as expected since a grammar has no need for two different forms with two identical sets of meanings. It will also be seen that the meanings of either pair of heteronyms do not coincide either, which was also expected since no two languages are exactly alike. Thus the grammar of the integrated bilingual speaker appears as a product of hybridisation.

Since on and sur, although not identical in their total semantic range, have some meanings in common, it is easy to see where the bilingual speaker might elect to attach either forms to a given meaning where as a monolingual would not. The two questions which this performance raises are : 1) why does he? 2) why should he not?

The first question can be answered by considering the on-in contact. These two particles are synonymous, i.e. interchangeable, to the extent that they have a certain number of meanings in common, and they are antonyms, i.e. not substitu- 
table, to the extent that they each have unshared meanings. In other words, they form a system in equilibrium : they share two elements (positive, vectorial) and are kept apart by two elements (contiguous, inclusive). The French prepositions sur and dans also form a system, but the balance is not the same; they share one meaning (vectorial) and are kept apart by four (contiguous, proportional, punctual, inclusive). Since in the mind of the bilingual two languages co-exist, we must also look at the systems formed across languages by heteronyms. English in and French dans form a system with two-shared elements (inclusive, vectorial) and two-unshared elements (positive, punctual); this system is similar in shape to the intralanguage system on-in; the same can be said of on-sur. We then have three comparable systems, and one which does not fit the general pattern. Since systematically organized data is easier to remember than random elements, one can speculate that the bilingual, in an effort to right the unbalanced load with which his memory is burdened, assigns to the asymetrical pair some of the properties of one of the symetrical pairs, thus creating a new grammar for himself and exhibiting interference in his performance.

This may show why interference occurs, but it does not explain why some utterances should not occur in one language while their exact translation may occur in the other.

In other words, we now know why people translate « he worked on the farm » as il a travaillé sur la ferme, but we don't know why it is possible to say un mystère planait sur la ferme and not travailler sur la ferme, unless some sort of restriction clause follows. We suggest that the answer can be found in the choice made by the speaker among the various meanings of the elements connected by means of the particle. Susan M. Ervin-Tripp (1969) has shown that after the selection of a given lexical or grammatical item has been made, the speaker is faced with a choice governed by social selectors. "Once a selection has been made,... later occurrences within the same utterance, conversation, or even between the same dyad, may be predictable. Whenever there is predictability between two linguistic forms, we can speak of co-occurrence rules. » (p. 113 et seq.). These may function along either of the syntagmatic and paradigmatic axes. In other words, having chosen a given lexical item and/or syntactical construction, the speaker must also decide how he is going to use it, and then abide by his decision, until at least a new utterance is initiated. Let us taken French ferme. We may think of it either as :

a) a legal arrangement

b) a material installation

c) a group of people

d) a type of work

The utterances we make thereafter will depend on which of these actualized meanings we chose to begin with. Thus for the set of cases above we may make the following set of utterances :

12) ayant perdu son père, il a perdu la ferme (loss of a right)

13) il a été arrêté pour avoir mis le feu à sa ferme (building)

14) on compte trois employés dans cette ferme (group of people)

15) il n'y a pas de fermes viticoles au Canada (type of work) 
In our example le mystère planait sur la ferme, the actualized meaning belongs to type three (people) while in il travaille dans une ferme, the actualized meaning is of type four (kind of work).

A similar operation with travailler gives us :

e) intellectual effort

f) physical labor

g) performance of specific operations

The next step is the choice of a proper particle to unite each actualized meaning of travailler and each actualized meaning of ferme. For example :

il travaille sur la ferme $=$ travailler $\mathrm{g}+$ ferme $\mathrm{b}+$ sur (contiguous) (e.g. he is repairing the roof)

il travaille dans une ferme $=$ travailler $\mathrm{f}+$ ferme $\mathrm{d}+$ dans (inclusion) (e.g. he is a farm laborer)

Since the meanings of English farm and to work are not in a one-to-one correspondence with their French counterparts (for the same reasons that on and sur are not) it follows that the same selection operation performed in English will yield a different utterance.

Since the operations outlined above are neither purely syntactic nor purely semantic (the speaker must make a choice from among various syntactic and semantic configurations) we suggest that they be classified as rules of language 《use » as opposed to language « usage ». The grammar of these rules, as they apply to the differential use of English and French, remains to be worked out in detail. But to return to our set of examples, we may already say that interference occurs not because the speaker is unaware of grammar rules, not because he is ignorant of the meaning of words, but because two factors combine to favor one utterance over the other : the variety of uses to which lexical items such as ferme and travailler lend themselves, and the imbalance of the semantic system governing the use of particles on, in, sur and dans. The latter explains why the error always follows the same direction, namely English into French.

\section{REFERENCES}

IRÈNE V. SPILKA

BrøNDAL, Viggo, Théorie des prépositions. Introduction à une sémantique rationnelle, traduction française par Pierre Naert, Copenhague, Ejnar Munksgaard, 1950.

Daswan, C. J., Adverbials of Time and Location in English : A Study in General Semantics, unpublished $\mathrm{Ph}$. D. thesis, Cornell, 1969.

Diebold, A. Richard, Jr., "Incipient Bilingualism", in Language in Culture and Society : A Reader in Linguistics and Anthropology, ed. by Dell Hymes, New York, Harper \& Row, 1964.

ERvin-Tripp, Susan M., " Sociolinguistics. », in Advances in Social Psychology, vol. 4 (1969) : 113-165.

Selinker, Larry, "Language Transfer », General Linguistics, 9 (1969) : 67-92.

WeInreich, Uriel, Languages in Contact : Findings and Problem, The Hague, Mouton, 1953. 